\title{
Sturge Weber Syndrome: A Case Report
}

\author{
Devkota $\mathbf{S}^{1}$, Upadhyay $\mathbf{S}^{2}$ \\ ${ }^{1}$ Dr. S. Devkota, MBBS, Medical Officer, ${ }^{2}$ Dr. Satyam Upadhyay, MBBS, MD. Lecturer, Both from the Department of \\ Paediatrics, Nepal Medical College and Teaching Hospital, Jorpati, Kathmandu, Nepal.
}

Address of Correspondence: Dr. Satyam Upadhyay, E-mail: satyam85@hotmail.com

\begin{abstract}
Sturge-Weber syndrome is a neurocutaneous syndrome characterized by port wine stain, congenital glaucoma, and underlying anomalous leptomeningeal venous plexus and the lack of normal cortical venous drainage. It is a congenital but not an inherited disease and it occurs sporadically and is very rare, incidence being approximately 1 on 50000 . It occurs with rare exception but occasionally the other members of the family may have hemangiomata of a lesser degree.
\end{abstract}

\section{Introduction}

$S_{s}$ urge-Weber syndrome is a neurocutaneous syndrome characterized by port wine stain, congenital glaucoma, and underlying anomalous leptomeningeal venous plexus and the lack of normal cortical venous drainage ${ }^{1}$. Sturge -Weber syndrome (SWS) is a rare disorder that occur with a frequency of approximately 1 per $50,000^{2}$. Sturge-Weber syndrome is a sporadic condition of mesodermal phakomatosis characterized by a portwine vascular nevus on the upper part of the face, leptomeningeal angiomatosis that involves cerebral hemispheres, choroidal vascular lesions associated with glaucoma, seizures, neurologic deterioration, and eventual neurodevelopmental delay ${ }^{3}$. These changes are usually unilateral and can be seen in both sexes equally with no racial differences ${ }^{4}$.

\section{Case Report}

A live term female appropriate for gestation was delivered to a primipara following vaginal delivery with face presentation with prolonged second stage of labour at Nepal medical College and Teaching Hospital (NMCTH). There was no significant Antenatal history and baby cried immediately after birth. On examination the baby was pink perfused, active limb movements were present. There were dark pink to red port wine stains in right half of the face. No evidence of any dysmorphism was noted. Cornea was hazy and no abnormalities in lip and palate were detected. Other system examinations were essentially normal. Opthalmological consultation was done and the baby was found to have bilateral congenital glaucoma for which she under went trabeculectomy with Mitomycin $\mathrm{C}$ in the right eye and trabeculotomy with Mitomycin $C$ in the left eye. There was also a history of single episode of partial seizure. However, CT scan and EEG revealed no abnormalities.

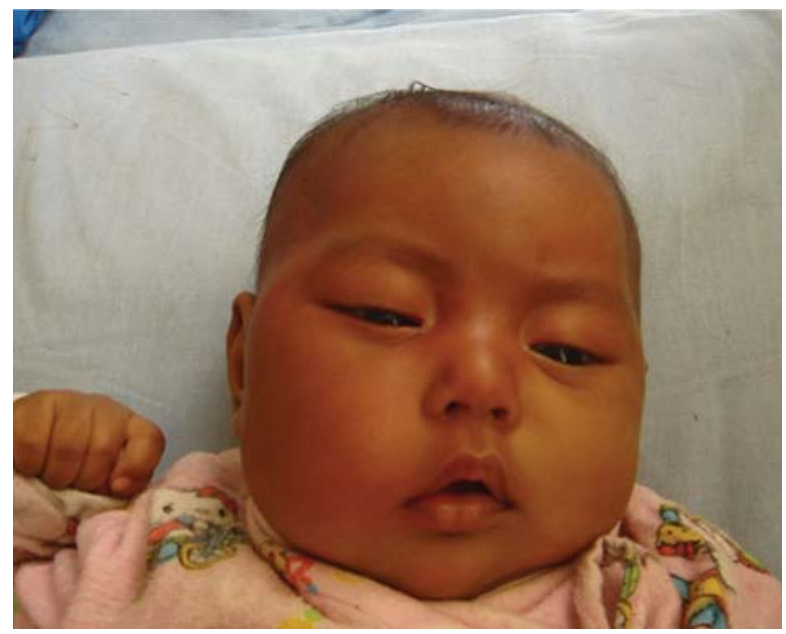

Fig 1: Portwine Stain on right side of face

\section{Discussion}

Sturge-Weber syndrome is a rare disorder that's characterised by neurological problems and a birthmark, known as a port-wine stain ${ }^{5}$. The birthmark may vary in color from deep purple to light pink and is caused by an overabundance of capillaries around the person's trigeminal nerve ${ }^{6,7}$. The syndrome can also be accompanied by a loss of nerve cells and calcification 
of tissue in the person's cerebral cortex of their brain on the same side of the body as their birthmark ${ }^{6}$. Glaucoma is the most common serious eye problem of SWS, with a reported incidence of $30-70 \%{ }^{8}$. Glaucoma may be present at birth or develop later. Pressure within the eye may damage the optic nerve, usually in the eye on the same side as the birthmark ${ }^{9}$. The reason for this increased eye pressure (glaucoma) may be the result of the outflow obstruction by a vascular malformation of the front area of the eye ${ }^{8}$. Convulsions occur in approximately $75 \%$ of patients, and $75 \%$ of the seizures appear within the first year of life. The majority of seizures are partial motor or complex partial types ${ }^{10}$. SWS is referred to as complete when both CNS and facial angiomas are present and incomplete when only 1 area is affected without the other. The Roach Scale is used for classification, as follows ${ }^{11}$.

- $\quad$ Type I - Both facial and leptomeningeal angiomas; may have glaucoma

- Type II - Facial angioma alone (no CNS involvement); may have glaucoma

- $\quad$ Type III - Isolated LA; usually no glaucoma

The diagnosis of Sturge-Weber syndrome can frequently be suspected when an infant is noted to have a facial port-wine birthmark associated with either brain or eye involvement ${ }^{10}$. Calcification in damaged cortical layer may become visible in X-ray skull and C.T. scan of brain. They are often Curvilinear and railroad track pattern on ipsilateral to port-wine stain. Usual site of calcification is occipital and posterior parietal lobes. But it can also affect other cortical regions and both cerebral hemispheres ${ }^{12}$. Although Cerebral calfication is usually not evident by radiography until later infancy ${ }^{13}$.

\section{References}

1. Doris D.M. Lin, P.B Barker, M.A. Kraut, Early Characteristics of Sturge-Weber Syndrome Shown by Perfusion MR Imaging and Proton MR Spectroscopic Imaging. Am J Neuroradiol 2003;24:1912-1915

2. Robert H.A. Haslam. Sturge - Weber disease, In Behrman RE, Kliegman RM, Jenson HB editors. Nelson's Textbook of Pediatrics, $17^{\text {th }}$ Ed, Philadelphia: Saunders; 2004.p.2017

3. Lee CW, Choi DY, Oh YG, Yoon HS, Kim JD,An Infantile Case of Sturge-Weber Syndrome in
Association with Klippel-Trenaunay-Weber Syndrome and Phakomatosis Pigmentovascularis. J Korean Med Sci 2005;20:1082-4

4. Govori V, Gjikolli B, Ajvazi H. Management of patient with Sturge-Weber syndrome; Cases Journal 2009;2:Accessed August 2010, Available from http://casesjournal.com/content/2/1/9394

5. Hicks R.BBC Health, Sturge-Weber syndrome, march 2009, Accessed August 2010.Available from http://www.bbc.co.uk/health/physical_health/ conditions/sturgeweber2.shtml

6. Weiss TC.Disabled world, disability and health news, published 2010 Feb 9, cited 2010 Aug 20. Available from:http://www.disabledworld.com/ health/neurology/sturge-weber-syndrome

7. Hennedige, Anusha A, Quaba, Sturge -Weber Syndrome and Dermatomal Facial Port-Wine Stains: Incidence, Association with Glaucoma, and Pulsed Tunable Dye Laser Treatment Effectiveness. $J$ Am Society of Plas Surgeons 2008;121(4):11731180.

8. Shannon LR, Fay A, Vascular Birthmark foundation, Glaucoma and Sturge Weber Syndrome Accessed August 2010.Available from http://vbfeurope.org/ glaucoma.php

9. Hobson C, Foyaca-Sibat H, Hobson B et al, Sturge Weber Syndrome Type I "Plus": The Internet Journal of Neurology. 2006;5: Available from http://www.britannica.com/bps/ additionalcontent/18/22760650/Sturge-WeberSyndrome-Type-I-Plus

10. Hsieh DT, Sarnat HB. Hypomelanosis of Ito with Sturge Weber Syndrome, published June 1997, cited August 2010.Available from http://www. medlink.com/medlinkcontent.asp

11. Roach E S. Neurocutaneous syndromes. Pediatr Clinic North Am 1992;39(4):591-620,cited August 2010. Available from http://emedicine.medscape. com/article/1177523-overview

12. Kumar V, Prasad BK, Sturge Weber Syndrome. Kathmandu Univ Med J 2004;2(8):372-74

13. Jones K L, Smith's Recognizable Patterns of Human Malformations, $6^{\text {th }} \mathrm{Ed}$, Elsevier: Saunders; 2006.p. 572.

\section{How to cite this article?}

Devkota S, Upadhyay S. Sturge Weber Syndrome: A Case Report. J Nep Paedtr Soc 2010;30(3):164-165. 